\title{
Branding and brand equity measurement in the beer industry of Thailand
}

\author{
Nisarat Aimkij ${ }^{1}$, Bahaudin G. Mujtaba ${ }^{2}$ \\ (1. Institute of International Studies, Ramkhamhaeng University, Bangkok 10240, Thailand; \\ 2. H. Wayne Huizenga School of Business and Entrepreneurship, Nova Southeastern University, Florida 33314, USA)
}

\begin{abstract}
The objective of this research is to investigate a new concept model of brand equity measurement in the economy beer industry of Thailand by using five factors of brand equity which are brand awareness, brand liking, brand purchase intention, brand satisfaction and brand loyalty along with the consumer behavior. The respondents are 379 males and females who have at least occasionally had a beer during the past few years. The findings show that males are more likely to drink beer regularly and in larger quantities. The average respondent seems to drink beer in order to relax and socialize at parties. Respondents recognize Leo beer more than the other two brands in this study. Descriptive statistics and statistical analysis are presented for individuals, managers, as well as for advertising and marketing professionals. Suggestions and links for personal brand building are also offered.
\end{abstract}

Key words: brand equity; brand awareness; brand liking; brand purchase intention; brand satisfaction; brand loyalty

\section{Introduction}

People trust quality products that they have tried before or those that demonstrate consistency over time, and they trust individuals whom they truly respect. In return, companies with a strong brand and leaders with a good image can capitalize on their name to gain a competitive advantage and sell products at premium prices. For example, today, Coca Cola's brand is worth around 70 billion dollars (Rampersad, 2009). It has also been said that McDonald's brand is worth around 25 billion dollars or more, and Media Giant, Oprah Winfrey's value is now estimated to be near 3 billion dollars. Think about the brand value of other individuals, companies and products in local and international markets as some professionals do excellent jobs in brand building. These strong brand values for products, companies and individuals did not just happen overnight, but rather came about through years of deliberate effort to grow their name and image.

In the 21st century, brand has been widely used to connect products with consumers' needs and wants (Bouti, 2010; Chan, Fine, Khanfar \& Mujtaba, 2009; Johnson \& Weinstein, 2004; Aaker, 1991). According to researchers, such as Aaker (1991), Kotler (1996), Morgan (2000), Johnson and Weinstein (2004), Mujtaba and McFarlane (2007), Keller (1993, 2008), Solomon (2010), Teng (2009) and others, brand names can have a huge impact on the general competitiveness of each product and on the consumers' decision on whether to purchase a product from

Nisarat Aimkij, Ph.D. candidate, Institute of International Studies, Ramkhamhaeng University; research fields: business and sales management.

Bahaudin G. Mujtaba, associate professor, H. Wayne Huizenga School of Business and Entrepreneurship, Nova Southeastern University; research fields: leadership and cross-cultural management. 
one company versus another. A strong brand can greatly influence a customer's purchase decision, and increase the overall value of a product in the marketplace (Cobb-Walgren, Cathy, Ruble \& Donthu, 1995; Johnson \& Weinstein, 2004). A good brand name can also provide a perception of more value in the minds of customers (Aaker, 1991; Pohlman \& Gardiner, 2000; Sangkaworn \& Mujtaba, 2010), and helps with the recruitment and retention of a loyal workforce (Udechukwu \& Mujtaba, 2007). Just like any other firm, in this competitive marketplace, it is important for all firms to become more market-oriented by understanding the needs, wants and perceptions of consumers in regards to their brands (Mujtaba \& McFarlane, 2007). Furthermore, researchers and firms can benefit from the history and success of other firms in a competitive environment (Ochoa \& Mujtaba, 2009). Effective research and continuous improvement toward better performance can provide a competitive advantage for a firm (Chalhoub, 2009; Jones \& George, 2009). This research will measure brand equity using the five factor model. This is a new concept to measure brand equity in the economy beer market of Thailand which is becoming more competitive as multinationals attempt to secure a larger share of the Thai Alcoholic beverage drinking market.

Beer industries tend to have three segments which are premium, standard and economy. During the economic crisis and internal political problems in Thailand, the beer market has been negatively impacted as some consumers have transitioned from drinking higher priced alcoholic beverages to lower priced ones. This transition has slowed down the revenues generated from the overall sales of products. Due to economic and political challenges, the overall industry has seen a $30 \%$ to $40 \%$ decrease in the sales of alcoholic beverages. There are three major companies in Thailand that produce economy beer and they are Thai Beverage Company Limited which sells Chang beer, Boonrawed Brewery Company Limited which sells Leo beer and Thai Asia Pacific Brewery Company Limited that sells Cheer beer. This study concentrates on these three firms and compares their products to each other as they make economy beer brands.

\section{Brands and the Thai economy}

The Thai government laws do not allow persons who are less than twenty years of age to purchase alcoholic beverages, and advertising is also limited, especially to underage populations. Beer advertising can be on television networks around midnight, this law applies to the regions within Thailand. Furthermore, the corporate income tax is set at a rate of $30 \%$ in Thailand, and beer companies also have to pay an excise tax on all of their alcoholic beverages. In January 2008, the government applied an additional amount of $1.5 \%$ onto the excise tax on all alcoholic beverages in Thailand in order to pay for the new public broadcasting system. In 2009, as if the current taxes were not enough, the Thai Government further applied an increase of 55\% to 58\% onto the excise tax on the beer industry of Thailand to generate revenue and perhaps to discourage excessive drinking (more information can be found at http://www.komchadluek.net).

Brand is basically a perception in the minds of consumers. The economy beer brands in Thailand are promoted as follows: (1) Leo beer is considered to be the quality beer which has smooth, great taste and has $5 \%$ alcohol content; (2) Chang beer is marketed toward the Thai taste albeit with international quality and 6.4\%

alcohol content; (3) Cheer beer is seen as an international quality beer at an affordable price. Cheer beer is perceived to be a high quality beer with a full-flavor, smooth taste, and $5.6 \%$ alcohol content.

The concept of "brand" was initially used in the 19th century as a registered trademark of a product. Since then brand has gradually transformed its value and meaning as it can impact purchasing behavior. Until the 21st 
century, brand has been widely used to connect products and consumer needs and wants. Brand is the name of products and services offered and a brand name tends to have a visual expression such as a symbol, a design, a trademark or a logo.

Brand is important because consumers decide to purchase products based on a brand name that they recognize due to past experiences or general marketing (Morgan, 2000). If the brand name is not recognized, then they may not feel certain about the quality of the product. So a "brand name" is important for the consumers' decision-making process. Brand equity focuses on the creation of a healthy relationship with consumers, and helps them decide on which products to purchase (Lassar, Mittal \& Sharma, 1995). Companies can use brand equity to create a market strategy that promotes the product to consumers and drives their decisions toward the purchase of the firm's products (Keller, 2008). Strong brand names have even been described as the ultimate competitive power for companies when market competition starts increasing. Competition forces firms and their brands to do many things to enhance their brand equity since it is often seen as the real capital of a business.

The business environment is becoming more and more competitive, partially due to new technologies and globalization which have enabled firms worldwide to offer different kinds of products at similar levels of quality and price. These similarities result in strong competition for the products in each market. In many cases, there may be little to no difference between the products offered by various local and international firms. So the importance of brand will be critical because it helps to build product differentiation and offers a basis for consumer decisions. Business is where money comes from in the form of products or services, and a strong brand is one strategy for how to differentiate a firm's product from its competitors, and to create an experience to added value while securing a long term competitive advantage in the marketplace.

So what exactly is a brand? According to Kothler and Keller (2006), a brand is a name, term, sign, symbol or design, or a combination of these, intended to identify the goods or services of a firm and to differentiate it in the minds of current and prospective consumers from the products and services offered by key competitors in the industry. A good brand can affect consumer behavior and decision making, and can help drive them to purchase the product while paying premium prices. For example, after Thai Beverage Company Limited introduced Chang beer in the economy beer market, Singha lost customers and revenue. Then Boonrawd Brewery Company Limited, which produces Shigha beer, could not compete on price strategy because this would cause a loss of brand image. They decided to enter the new market for low cost beer with the Leo brand, an economy beer. Leo beer entered the new market at a price of three bottles for 100 baht (approximately \$3), which decreased the growth of sales for Chang beer. After these two firms had built economy beer brands, Thai Asia Pacific brewery tried to come up with their own economy beer with the Cheer brand. Furthermore, other economy beer firms from overseas are entering the new market in Thailand. Whether national or international, the brand name can create a competitive advantage for a firm and its products.

It can be said that the brand of each beer is developed through continuous image building, and they never stop developing their products or the perception of their consumers in order to satisfy their consumers and benefit from a competitive advantage. The brand equity in the beer industry is constantly moving up or down and changing all the time since there is always going to be a comparison between brand equity and the brand name of each product.

Brand equity measurement can be calculated in many ways. This study used the five factor brand equity measurements model which is based upon the work of Aaker $(1991,1996)$. This study uses the five factor brand equity to test the economy beer industry because the beer market has high competition and each firm in the 
industry is trying to build strong brand identity. It is hoped that this study may offer a guide for applying the benefits of brand equity in practice. This will enhance consumer understanding of brand equity measurement of approval of products.

The brand equity can provide a common denominator for interpreting the market strategy and assessing the value of a brand. Measuring brand equity is a set of research procedures that is designed to provide timely, accurate and actionable information for marketers so that they can make the best possible tactical decisions in the short run, and strategic decisions in the long-run (Keller, 2008, p.102).

The three main aspects of brand equity are the financial perspective, the customer-based perspective, and the combined perspective (Keller, 1993). This study focuses on the customer-based perspective of brand equity. The operationalization of customer-based brand equity can be divided into consumer perception such as brand awareness, brand liking, and brand satisfaction or consumer behavior which can be inclusive of brand purchase intention and brand loyalty (Morgan, 2000). A customer-based brand equity perspective is an indirect approach to measuring brand equity as it attempts to assess potential sources for brand equity by measuring consumer mindset. The indirect approach is useful in identifying various aspects of the brand equity that creates a differential response of consumers in the marketplace.

According to Aaker (1991), brand equity is a set of five categories of brand assets and liabilities linked to a brand, its name, and symbol that add to or subtract from the value provided by a product or service to a firm or to that firm's customers, or both. The categories of brand assets are brand loyalty, brand awareness, perceived quality, brand associations and other proprietary assets (e.g., patents, trademarks and channel relationship). To examine the common dimensions of brand equity, while adapting David Aaker's model (1991), this study created an alternative model for brand awareness, brand liking, brand satisfaction, brand purchase intention and brand loyalty. The alternative model of brand equity measurement in this research, as seen in Fig. 1, includes the factors of brand awareness, liking, purchase intention, satisfaction and loyalty.

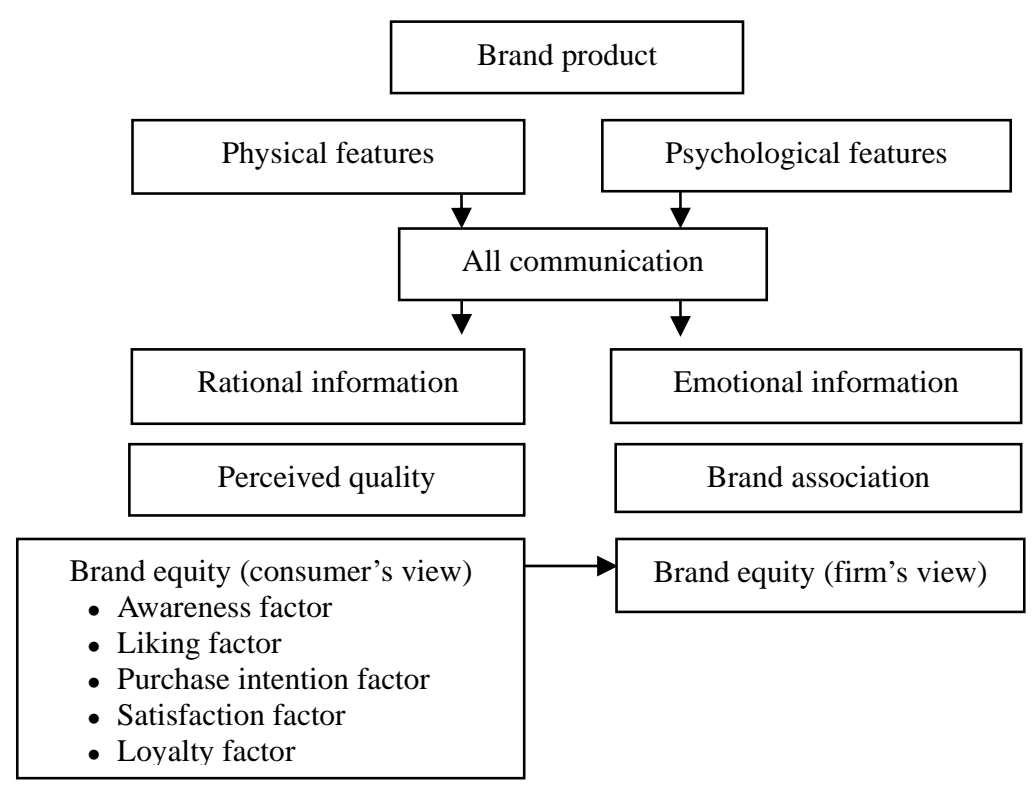

Fig. 1 The five factor brand equity model

By using this five factor brand equity test, researchers can gather information about branded products which 
include physical features and psychological features. The communication process in the five factor model of information can be separated into two parts:

(1) Rational information that exemplifies product criteria such as shapes, color, etc.

(2) Emotional information that exemplifies male/female humanity, universality, the concept of looking smart, luxury and others.

Generally, two types of information impact brand equity in perceived quality and brand association. Of course, quality perceptions and brand associations comes from consumers' experiences with the product or the firm's overall brand. So the five factors that brand equity measurement concept assesses in the mind of consumers is the overall value or brand equity. The total perception of all factors are then added together to find the mean brand equity by attitude components.

(1) Brand awareness

Brand awareness is the ability of a potential buyer to recognize or recall that a brand is a member of a certain product category so he/she can establish a link between product class and brand (Aaker, 1991, p.61). Brand awareness plays an important role in decision making of customers. If a consumer has already heard of the brand name, the customer would feel more comfortable at the time of making a purchase decision. Customers usually do not buy an unknown brand because an unknown brand cannot be trusted to have good and reliable quality. Generally, consumers tend to buy brands that are familiar to them and products that they are confident about. A well known brand can get an opportunity to be purchased because of brand awareness. Brand association together with awareness, emotion and basic attributes (image, prestige) allows customers to make a statement based on their feelings and personal life styles.

(2) Brand liking

Brand liking has to do with distinguishing a product from the more traditional notions of brand, product, image or related qualities that predispose consumers to buy or use a particular brand. Brand liking seeks to build consumers' positive attitudes toward a brand (or company) based on the belief that it cares about them (or addresses their needs) as individuals, not just purchasers and users of its products. In other words, brand liking is about building relationships and bonding with consumers by addressing them as individuals (Boutie, 1994, p.4).

(3) Brand purchase intention

Brand purchase intention shows a customer's preference to purchase the product, whose image is very close to what the customers believe it is. Moreover, customers are well aware of certain brand names through advertising from their past experiences or information from their friends (Teng, 2009, p.15). The purchase intention of a consumer to purchase a particular brand can be defined as his/her willingness to buy that brand.

(4) Brand satisfaction

Brand satisfaction is processing decisions based upon previous post purchase evaluations, which means that the consumer has past experience with the product, and the satisfaction factor for the brand. The evaluation will show consumers' level of satisfaction with the brand. This factor measures the brand name of products and can gain information on consumer behaviors and attitudes such as reactions to physical impression and psychological impression. The level of consumer satisfaction can increase or decrease after using a product.

(5) Brand loyalty

Brand loyalty shows consumers' preference to purchase specific brands that customers believe have a good feature, image, and/or quality at the right price. Brand loyalty is shaped by the continued purchases of a product in an intentional manner on a regular basis (Solomon, 2008, p.293). 
The brand loyalty of the customer base is often the core of brand equity. If customers are indifferent to the brand, but in fact buy with respect to features and price with little concern to the brand name, then there is likely little brand equity. If on the other hand, they continue to purchase the brand even when competitors provide superior features, prices and convenience, substantial value exists in the brand and perhaps in its symbol and slogan (Aaker, 1991, p.39). As demonstrated by the example Johnson and Johnson's Tylenol case, it is well documented that trust in a brand can lead to loyalty for the product and a company's general brand. Toyota's crises with the accelerating gas pedal of certain cars in eight different models present a huge problem for the long-term value of their brand. Toward the end of January 2010, Toyota dealers stopped selling cars in eight of their popular models until they are able to fix the problem and guarantee the safety of their customers. This impacts nearly four million of their cars. How well, and how fast, Toyota managers deal with this new and unprecedented challenge will determine the decrease in the overall value of the "Toyota" brand. In the process of damage control in this major challenge for them, Toyota leaders must demonstrate a concern for the safety of their customers and the quality of their cars.

\section{Research methodology}

It is important for researchers to study new models that have not been studied before for evaluating the economy beer market in Bangkok province, Thailand. The findings of this study could help companies to design and develop new marketing strategies for their products. Furthermore, a company can think of different ways to communicate with consumers based on the brand equity model. This study considered the following five hypotheses:

(1) Hypothesis 1: The brand awareness of each beer brand is different.

(2) Hypothesis 2: The brand liking of each beer brand is different.

(3) Hypothesis 3: The brand purchase intention of each beer brand is different.

(4) Hypothesis 4: The brand satisfaction of each beer brand is different.

(5) Hypothesis 5: The brand loyalty of each beer brand is different.

The collection of data is the primary and secondary phase. The study focused on the analysis of brand equity measures in the economy beer industry using quantitative research data. The three firms that produce economy beer in Thailand and 379 respondents, who live in Bangkok, are the subjects of this study to evaluate the implementation of five factors brand equity measure. Most respondents were employed males and had an education level of bachelors' degree. The average income is about 10,000 to 20,000 baht ( $\$ 300$ to $\$ 600$ ) per month, which is a typical average salary for employees in Thailand.

The data analysis was limited to the use of the following statistical tools: frequencies and percentages and Analysis of Variance (ANOVA). Table 1 presents the number and percentages of the respondents along with the demographic (personal) profile in terms of gender, age, education, occupation and income.

Table 2 shows the number and percentage of the respondents in terms of consumer behavior. The questionnaire checklist was used as the instrument data. It consists of brand equity measures such as brand awareness, brand liking, brand purchase intention, brand satisfaction and brand loyalty. Questionnaires were distributed to the respondents and retrieved by the first author.

Descriptive statistics for the five factors of brand equity contains information on brand awareness, brand liking, brand purchase intention, brand satisfaction and brand loyalty. 
Branding and brand equity measurement in the beer industry of Thailand

Table 1 Demographic profile of respondents

\begin{tabular}{|c|c|c|}
\hline Variable & Number (\#) & Percent (\%) \\
\hline Gender & 379 & 100.0 \\
\hline Male & 283 & 74.7 \\
\hline Female & 96 & 25.3 \\
\hline Age & 379 & 100.0 \\
\hline Below 25 & 73 & 19.3 \\
\hline $25-35$ & 90 & 23.7 \\
\hline $36-45$ & 161 & 42.5 \\
\hline $46-55$ & 51 & 13.5 \\
\hline More than 55 & 4 & 1.1 \\
\hline Education & 379 & 100.0 \\
\hline Less than secondary & 79 & 20.8 \\
\hline Secondary & 47 & 12.4 \\
\hline High school & 61 & 16.1 \\
\hline Diploma & 29 & 7.7 \\
\hline Bachelor's degree & 151 & 39.8 \\
\hline Higher than Bachelor's & 12 & 3.2 \\
\hline Occupation & 379 & 100.0 \\
\hline Student & 68 & 17.9 \\
\hline Employee & 145 & 38.3 \\
\hline Government agent & 81 & 21.4 \\
\hline State enterprises & 11 & 2.9 \\
\hline Entrepreneur & 27 & 7.1 \\
\hline Other & 47 & 12.4 \\
\hline Income & 379 & 100.0 \\
\hline Less than 5,000 & 21 & 5.5 \\
\hline $5,000-10,000$ & 202 & 53.3 \\
\hline $10,001-20,000$ & 134 & 35.4 \\
\hline $20,001-30,000$ & 16 & 4.2 \\
\hline $30,001-40,000$ & 3 & 0.8 \\
\hline More than 40,000 & 3 & 0.8 \\
\hline
\end{tabular}

Table 2 Consumer behavior of the respondents

\begin{tabular}{|c|c|c|}
\hline Variable & Number (\#) & Percent (\%) \\
\hline Work in beverage/Advertising? & 379 & 100.0 \\
\hline Yes & 0 & 0.0 \\
\hline No & 379 & 100.0 \\
\hline Have you had a beer drink? & 379 & 100.0 \\
\hline Yes & 379 & 100.0 \\
\hline No & 0 & 0.0 \\
\hline When do you drink beer? & 379 & 100.0 \\
\hline Party & 141 & 37.2 \\
\hline Relax & 162 & 42.7 \\
\hline Every occasional & 36 & 9.5 \\
\hline With friends & 27 & 7.1 \\
\hline Between meals & 13 & 3.4 \\
\hline Which beer bran do you drink? & 379 & 100.0 \\
\hline Chang & 66 & 17.4 \\
\hline Leo & 308 & 81.3 \\
\hline Cheer & 5 & 1.3 \\
\hline Frequency of beer drinking & 379 & 100.0 \\
\hline Once/week & 97 & 25.6 \\
\hline 2-3 times/week & 144 & 38.0 \\
\hline 4-6 times/week & 30 & 7.9 \\
\hline Everyday & 35 & 9.2 \\
\hline Not too often & 73 & 19.3 \\
\hline Quantity of beer each time & 379 & 100.0 \\
\hline Below 1 bottle/can & 31 & 8.2 \\
\hline 1 bottle/can & 165 & 43.5 \\
\hline 2-3 bottle/can & 115 & 30.3 \\
\hline 4-5 bottle/can & 22 & 5.8 \\
\hline More than 6 bottle/can & 46 & 12.1 \\
\hline
\end{tabular}




\subsection{Brand awareness}

Table 3 shows the number and percentage of the respondents who think about the brand. The majority of respondents are thinking about Leo beer as an economy beer (290 respondents, 76.5 percent of the sample). Chang beer is the number two with 82 respondents, which is 21.7 percent, and Cheer beer is ranked third with 1.8 percent of the respondents. The respondents think about Leo beer more than either the Chang or Cheer brands.

Table 3 Thinking about the brand

\begin{tabular}{lcc}
\hline \multicolumn{1}{c}{ Variable } & Frequency & Percent (\%) \\
\hline Think about economy beer & 379 & 100.0 \\
Chang & 82 & 21.7 \\
Leo & 290 & 76.5 \\
Cheer & 7 & 1.8 \\
\hline
\end{tabular}

Table 4 shows the number and percentage of the respondents' awareness by symbol or sign. The respondents recognize the economy beer by symbols or sign of Chang, Leo and Cheer beer. The respondents that recognize the Leo symbol make up a total of 379 respondents (100 percents), Chang symbol is recognized by 379 respondents (100 percents), and the Cheer symbol had 246 respondents (64.9 percent). The respondents mostly say that they know the Leo and Chang beer symbols more than Cheer beer. Perhaps this is because Cheer is new in the economy beer market.

Table 4 Respondents who recognized the symbol

\begin{tabular}{lccc}
\hline & Description & Know & Unknown \\
\hline Percent (\%) & 100.0 & 100.0 \\
Chang symbol & 100.0 & 0.0 \\
Leo symbol & 100.0 & 0.0 \\
Cheer symbol & 64.9 & 35.1 \\
\hline
\end{tabular}

Table 5 shows that respondents consider other items when drinking beer. The data show that a majority of them (211 respondents or 55.7\%) think about ice when drinking beer. This is because ice can make beer feel cool and fresh, in spite of the fact that the ice may cause taste changes in the beer. About 89 (23.5\%) respondents consider food when drinking beer, ranked number 3 is friends with 46 (12.1\%), ranked number four is beer foam with 18 (4.7\%), and lastly other items had 15 (4.0\%) responses. The other items can be anything such as telephone (talking), boss/ manager, watching television or having a specific snack.

Table 5 Things to consider when drinking beer

\begin{tabular}{lcc}
\hline & Frequency & Percent (\%) \\
\hline First consider & 379 & 100.0 \\
Ice & 211 & 55.7 \\
Food & 89 & 23.5 \\
Friends & 46 & 12.1 \\
Beer foam & 18 & 4.7 \\
Other & 15 & 4.0 \\
\hline
\end{tabular}

Table 6 shows the number and percentage of the respondents who selected economy beer brands. The data shows that the number one recall is for Leo beer (285 respondents, 75.2 percent), the number two recall is for Chang beer (285 respondents, 75.2 percent) and the number three recall is for Cheer beer (351 respondents, 92.6 percent). The number of respondents recalling Chang and Leo beers is the same, but respondents chose Leo beer as their number one choice when deciding to have a drink, Chang beer as their number two, and the third was the 
Cheer beer.

Table 6 First recall of economy beer brands

\begin{tabular}{lccc}
\hline \multicolumn{1}{c}{ Rank number } & Number one & Number two & Number three \\
\hline Percent (\%) & 100.0 & 100.0 & 100.0 \\
Chang beer & 18.5 & 75.2 & 6.3 \\
Leo beer & 75.2 & 23.5 & 1.3 \\
Cheer beer & 5.8 & 1.6 & 92.6 \\
\hline
\end{tabular}

\subsection{Brand liking}

Table 7 shows the percentage of the respondents liking the details of the products. Chang beer had a 37.2 percent of the respondents that liked the retail price, 59.4 percent were neutral on the packaging (container), advertising and media had a 48.8 percent response rate, and 52.2 percent were neutral on brand liking rank.

Leo beer had a 34.6 percent of the respondents who liked Leo beer's retail price, 52.5 percent were neutral on packaging (container), 55.9 percent liked the advertising and media, and 65.2 percent had preference on brand liking rank.

Cheer beer had a 41.7 percent of the respondents disliked Cheer beer's retail price, 45.4 percent were neutral on packaging (container), 42 percent disliked the advertising and media, and 45.4 percent dislike the brand all together.

Table 7 Brand liking of the economy beer

\begin{tabular}{lcrrrr}
\hline \multicolumn{1}{c}{ Brand/By percent } & Strongly like & \multicolumn{1}{c}{ Like } & Neutral & Dislike & Strongly dislike \\
\hline Chang & 100.0 & 100.0 & 100.0 & 100.0 & 100.0 \\
Retail price & 15.9 & 37.2 & 34.6 & 9.8 & 2.9 \\
Packaging & 4.0 & 5.0 & 59.4 & 30.3 & 1.3 \\
Adv. \& Media & 3.2 & 2.9 & 41.2 & 48.8 & 4.0 \\
Brand prefer & 5.3 & 29.8 & 52.2 & 10.6 & 2.1 \\
Leo & & & & & 100.0 \\
Retail price & 100.0 & 100.0 & 100.0 & 100.0 & 5.8 \\
Packaging & 9.2 & 34.6 & 29.0 & 21.4 & 0.0 \\
Adv. \& Media & 3.7 & 37.7 & 52.5 & 6.1 & 0.5 \\
Brand prefer & 4.2 & 30.1 & 55.9 & 9.2 & 0.5 \\
Cheer & 8.7 & 65.2 & 22.4 & 3.2 & 100.0 \\
Retail price & & & & & 100.0 \\
Packaging & 100.0 & 100.0 & 100.0 & 100.0 & 7.7 \\
Adv. \& Media & 2.4 & 10.8 & 27.2 & 41.7 & 32.7 \\
Brand prefer & 1.6 & 12.7 & 45.4 & 42.0 & 19.0 \\
\hline
\end{tabular}

The respondents like Leo beer as their first choice, Chang beer is second and Cheer beer is third. For some of the respondents Cheer beer is totally unknown because this product is not popular yet, but the firm also sells Heineken which is better known in the Thai market. The analysis of the factors was based on the following four elements: (1) liking the price, (2) liking the packaging, (3) liking the advertising, and (4) developed a liking to the overall brand. It was found that the Leo beer brand has apparently developed a strong brand, but their packaging and price are unnecessarily any better than their competitors. This research shows that the most important component that consumers prefer in Leo beer is the best brand. The sample group chose Chang beer as the number two popular beer in this study. Cheer beer is the third perhaps because its price is considered to be expensive for the overall value and their ads are not always visible.

\subsection{Brand purchase intention}


Table 8 provides the purchase intention data which shows that the respondents chose Leo beer as their number one choice, Chang beer as the number two choice and Cheer beer is the number three. Although the respondents liked the price of Chang beer more than Leo beer, when purchasing they chose Leo beer.

Table 8 The respondent purchase decision on beer brand

\begin{tabular}{lccccc}
\hline & Want to buy & Must buy & Not sure & Must not buy & Don't want to buy \\
\hline Percent (\%) & 100.0 & 100.0 & 100.0 & 100.0 & 100.0 \\
Chang & 9.0 & 54.6 & 22.7 & 10.0 & 3.7 \\
Leo & 56.2 & 33.0 & 9.8 & 1.0 & 0.0 \\
Cheer & 2.4 & 10.0 & 21.9 & 38.5 & 27.2 \\
\hline
\end{tabular}

The sample group reported greater satisfaction on purchases of Leo beer than for either Chang beer or Cheer beer. But Chang beer is still in the second place, and more respondents would rather purchase Chang than Cheer beer. The research showed that consumers were satisfied with and intend to purchase Leo beer and Chang beer. People are likely to purchase Leo beer more than the Chang or Cheer brands. This is because the majority of the respondents had consumed Singha beer before, and Leo beer is manufactured by the same company in Thailand.

\subsection{Brand satisfaction}

Table 9 shows the percentage of respondents in brand satisfaction of the three beer brands. For Chang beer, there were 177 respondents (46.7 percent) that were satisfied with the taste, 221 (58.3 percent) respondents felt it is fresh, and 205 respondents (54.1percent) felt satisfied when drinking it.

For Leo beer, there were 270 respondents (representing 71.2 percent) who were satisfied with the taste, 277 respondents (73.1 percent) felt it is fresh, and 261 respondents (68.9 percent) felt satisfied drinking it.

Table 9 The respondents in brand satisfaction of the three beer brands

\begin{tabular}{lcrrrr}
\hline Brand/By percent & Strongly satisfied & Satisfied & Neutral & Not satisfied & Strongly dissatisfied \\
\hline Chang & 100.0 & 100.0 & 100.0 & 100.0 & 100.0 \\
Taste & 3.2 & 46.7 & 35.4 & 13.5 & 1.3 \\
Feeling fresh & 0.0 & 26.1 & 58.3 & 13.5 & 2.1 \\
Satisfy to drink & 1.8 & 26.9 & 54.1 & 16.1 & 1.1 \\
& & & & & 100.0 \\
Leo & 100.0 & 100.0 & 100.0 & 100.0 & 0.0 \\
Taste & 9.2 & 71.2 & 15.0 & 4.5 & 0.0 \\
Feeling fresh & 10.0 & 73.1 & 16.1 & 0.8 & 0.0 \\
Satisfy to drink & 11.6 & 68.9 & 18.7 & 0.8 & 100.0 \\
& & & & & 9.2 \\
Cheer & 100.0 & 100.0 & 100.0 & 100.0 & 8.7 \\
Taste & 0.8 & 17.2 & 29.6 & 43.3 & 9.2 \\
Feeling fresh & 0.8 & 8.2 & 39.8 & 42.5 & 44.9 \\
Satisfy to drink & 1.3 & 10.8 & 33.8 & & \\
\hline
\end{tabular}

For Cheer beer, there were 164 respondents (representing 43.3 percent) who were not satisfied with the taste of this beer. In regards to feeling fresh, about 161 respondents (representing 42.5 percent) were not satisfied, and in regards to satisfaction of drinking Cheer beer, 170 respondents (44.9 percent) stated that they were not satisfied.

The sample group has satisfactory experiences with Leo beer, followed by Chang beer, and Cheer beer is in last place. When analyzing the composition of the factors on brand satisfaction, there are three areas: (1) the consumer's satisfaction, (2) satisfaction after using the products, and (3) the opportunity to purchase. Leo beer seems to be more satisfactory with consumers. Satisfaction with the level of physical product such as taste, odor, color, and foam was very high. The level of satisfaction for purchasing the Leo brand of beer is relatively high when compared to Chang beer and Cheer beer. The study found that the sample group's reactions to Cheer beer 
served to minimize both physical interest and the intention to purchase in the future. The conclusion is that consumer interest in brands influences the next purchase or their buying behavior.

\subsection{Brand loyalty}

Table 10 shows the frequency and percentage of brand loyalty among consumers. A fairly large percentage of consumers reportedly drink Leo beer is 309 (81.5 percent), followed by Chang beer which is 53 (14 percent), and then Cheer beer is 17 (4.5 percent). Data show that Leo beer has more loyalty from its consumers than the other brands.

Table 10 Loyalty of the chosen beer brands

\begin{tabular}{lccc}
\hline & Variable & Frequency & Percent \\
\hline Regular drink on brand & 379 & 100.0 \\
Chang & 153 & 17.0 \\
Leo & 309 & 81.5 \\
Cheer & 17 & 4.5 \\
\hline
\end{tabular}

Table 11 shows that a high percentage of the respondents chose Leo beer perhaps because they are loyal to this brand. The data shows the respondents that have confidence in the product at a "high" level is 187 (49.3 percent), "advantage" on proud to drink is 217 (57.3 percent) and "advantage" on wanting to drink this beer again is 229 (60.4 percent). Overall, researchers can analyze the factors for the elements of brand loyalty in four factors: (1) always purchase brand, (2) brand trust on quality, (3) be proud to use the brand, and (4) only want that brand.

Table 11 Loyalty of Leo brand by feeling, taste and desire

\begin{tabular}{lcccrr}
\hline \multicolumn{1}{c}{ Brand/By percent } & High & Rather high & Advantage & Rather low & Low \\
\hline Leo beer & 100.0 & 100.0 & 100.0 & 100.0 & 100.0 \\
Confident & 6.1 & 49.3 & 43.4 & 1.3 & 0.0 \\
Feel proud & 9.2 & 21.9 & 57.3 & 10.8 & 0.0 \\
Want to drink & 7.1 & 29.3 & 60.4 & 3.2 & 0.0 \\
\hline
\end{tabular}

The Analysis of Variance (ANOVA) was used to determine the five factors of brand equity measurement practice. This can be used to assess the effect of the various elements when comparing three or more means. The five hypotheses related to the research questions were analyzed based on the results of the theoretical model.

Table 12 ANOVA for "brand awareness of each beer is different"

\begin{tabular}{lccccc}
\hline \multicolumn{1}{c}{ Source } & SS & df & MS & F & Sig. \\
\hline Between groups & 30.223 & 2 & 15.112 & 202.328 & 0.000 \\
Within groups & 84.024 & 1125 & 0.075 & & \\
Total & 114.247 & 1127 & & & \\
\hline
\end{tabular}

Note: Significance $=0.000<0.05$.

Table 12 shows that the between-groups estimate of the variance is 15.112 and the within-groups estimate is 0.075. The $F$ test statistic is 202.328 and the Significance of the test is equal to 0.000 and less than 0.05 . So the null hypotheses which states that there is no significant difference in the brand awareness of each beer is rejected, which means brand awareness on each beer brand is different. The respondents' level of awareness for Chang and Leo beer are similar, but for Cheer beer the respondents' awareness is different and significantly lower than the other two brands.

Therefore, in a match between competing brands, it is necessary to create a sense of the brand over the competition. Order of recall and brand image is components of the analysis of the composition of brand awareness 
factors. It was established that Leo beer is the economy beer with the highest brand awareness.

Table 13 shows that the between-groups estimate of the variance is 79.035 and the within-groups estimate is 0.385. The $F$ test statistic is 205.067 and the Significance of the test is equal to 0.000 and less than 0.05 . So the null hypothesis which states that there is no significant difference for brand liking $\left(\mathrm{H}_{0}\right)$ is rejected, which means brand liking for each beer brand is different. The respondents ranked Leo beer as number one, Chang beer as number two, and Cheer beer as number three in brand liking.

Table 13 ANOVA for "brand liking of each beer is different"

\begin{tabular}{lccccc}
\hline \multicolumn{1}{c}{ Source } & SS & df & MS & F & Sig. \\
\hline Between groups & 158.071 & 2 & 79.035 & 205.067 & 0.000 \\
Within groups & 437.058 & 1134 & 0.385 & & \\
Total & 595.129 & 1136 & & & \\
\hline
\end{tabular}

Note: Significance $=0.000<0.05$.

Table 14 shows that the between-groups estimate of the variance is 474.898 and the within-groups estimate is 0.806 . The $F$ test statistic is 589.141 and the significance of the test is equal to 0.000 and less than 0.05 . So the null hypothesis which states that there is no significant difference in purchase intention for each beer is rejected, which means brand purchase intention on each beer is different. The respondents would purchase Leo beer as their number one choice, followed by Chang beer as number two, and Cheer beer as the third option.

Table 14 ANOVA for "brand purchase intention of each beer is different"

\begin{tabular}{lrrrrl}
\hline \multicolumn{1}{c}{ Source } & SS & df & MS & F & Sig. \\
\hline Between groups & 949.796 & 2 & 474.898 & 589.141 & 0.000 \\
Within groups & 914.100 & 1134 & 0.806 & & \\
Total & 1863.896 & 1136 & & & \\
\hline
\end{tabular}

Note: Significance $=0.000<0.05$.

Table 15 shows that the between-groups estimate of the variance is 190.467 and the within-groups estimate is 0.533. The F test statistic is 357.218 and the significance of the test is equal to 0.000 and less than 0.05 . So the null hypothesis which states that there is no significant difference in brand satisfaction of each beer is rejected, which means brand satisfaction with each beer is different. The respondents ranked satisfaction with Leo beer as number one (highly satisfied), Chang beer as number two and Cheer beer as number three.

Table 15 ANOVA for "brand satisfaction of each beer is different"

\begin{tabular}{lccccc}
\hline \multicolumn{1}{c}{ Source } & SS & df & MS & F & Sig. \\
\hline Between groups & 380.934 & 2 & 190.467 & 357.218 & 0.000 \\
Within groups & 604.644 & 1134 & 0.533 & & \\
Total & 985.578 & 1136 & & & \\
\hline
\end{tabular}

Note: Significance $=0.000<0.05$.

Table 16 shows that the test statistics $F$ value is 14.941 for feeling confident in quality, 5.060 for feeling proud of, and 5.345 for feeling like drinking this beer brand. The significance of the test is equal to $0.000,0.007$ and 0.005 which are less than 0.05 . So the null hypothesis which states that there is no significant difference in brand loyalty of each is rejected, which means brand loyalty for each beer is different. This means that the brand loyalty is important for consumers to trust the quality of the product. 
Table 16 One-Sample test of "brand Loyalty for each beer is different"

\begin{tabular}{|c|c|c|c|c|c|c|}
\hline & & SS & df & MS & $\mathrm{F}$ & Sig \\
\hline \multirow{3}{*}{ Feel confident in the quality } & Between group & 10.810 & 2 & \multirow{3}{*}{$\begin{array}{l}5.405 \\
0.362\end{array}$} & \multirow{3}{*}{14.941} & \multirow{3}{*}{0.000} \\
\hline & Within group & 136.029 & 376 & & & \\
\hline & Total & 146.839 & 378 & & & \\
\hline \multirow{3}{*}{ Feel proud of owning product } & Between group & 6.457 & 2 & \multirow{3}{*}{$\begin{array}{l}3.229 \\
0.638\end{array}$} & \multirow{3}{*}{5.060} & \multirow{3}{*}{0.007} \\
\hline & Within group & 239.896 & 376 & & & \\
\hline & Total & 246.354 & 378 & & & \\
\hline \multirow{3}{*}{ Feel like drinking this beer brand } & Between group & 4.678 & 2 & 2.339 & \multirow{3}{*}{5.345} & \multirow{3}{*}{0.005} \\
\hline & Within group & 164.557 & 376 & \multirow[t]{2}{*}{0.438} & & \\
\hline & Total & 169.235 & 378 & & & \\
\hline
\end{tabular}

Note: Significance $=0.000<0.05$.

\section{Implications and recommendations}

This study was conducted to investigate the five factor brand equity measurement of economy beer in Thailand. The study is quantitative research that used the survey method and collected data from respondents living and working in Bangkok, Thailand. Based on brand equity and attitude theories, brand equity was defined and developed through the theoretical model.

This research sought to understand what and how consumers might think about brand satisfaction in order to understand both consumer and firm thinking. The constructs of brand awareness, brand liking and brand loyalty were satisfied. It is proposed that brand awareness is positively related to brand liking in the new concept. Moreover, brand liking was argued to be positively related to brand loyalty. This means that if consumers become satisfied with doing business with the brand manufacturer and perceive this brand as providing good value for consumers, a positive image of brand will be imprinted in their minds which can influence future purchases. Of course, firms can always capitalize on their strong brands to gain more revenues and new business. Companies like Coca Cola and Disney World have built a strong global brand for themselves. For example, the Disney brand stands for fun, excitement and recreation, and this image has allowed them to be successful in North America, Europe and in Asia (Karadjova-Stoev \& Mujtaba, 2009). Managers and cast members (employees) at Disney are trained to work hard and learn from their mistakes, while consistently meeting or exceeding even the expectations of their youngest guests.

The research that has been employed in this study leads to several recommendations on the different approaches for further exploration of the issues investigated here. The five factor model of brand equity should be studied for long term planning and impact. Consumers should be surveyed in different places, and definitely in two or more provinces. Finally, based on the conclusions of the study, the following suggestions and recommendations are offered:

(1) All firms and individuals must be clear about their brands. A brand is the overall image of the person or firm in the minds of others.

(2) Companies should create an effective strategy for enhancing their brand value through product quality, service quality, clear and consistent communication with employees and customers and always trying to meet or exceed customers' expectations.

(3) Organizations that desire to have a strong brand must also provide quality training programs for their employees, managers and suppliers about properly promoting, enhancing and maintaining the brand value.

(4) The economy beer firms in Thailand should become more active in the research of brand perceptions. 
They should also continue to work on assessing the views of their customers and constantly improve their products.

(5) Beer companies should also consider the social impact of their advertising, while always obeying the local laws and customs of each locality.

(6) The alcoholic beverage businesses need to carefully communicate the facts about the advantages and disadvantages of excessive beer consumption to all their consumers.

(7) Future studies should consider the preferences of males and females. Different generations should also be segmented to see if their drinking preferences and branding perceptions vary. As demonstrated by Murphy Jr., Mujtaba, Manyak, Sungkhawan and Greenwood (2010) as well as Mujtaba, Luk, Murphy Jr. and Saowakul (2009), the various generations in Thailand have different terminal and instrumental values. Therefore, they might respond differently to various branding and advertising initiatives.

This study demonstrated that chiseling or building a strong brand is very important as it can provide a sustainable competitive advantage for a firm and its products. Generally speaking, it should be noted that every professional in the workplace and every individual in society should be exposed to the importance and value of brands for his or her own personal image. As emphasized by Hubert Rampersad (2009), everyone has a personal brand which is inclusive of what one thinks it is and, in reality, what others perceive his/her value to be. It is good to start by being idealistic and envision a great brand for oneself. However, one must also be realistic by assessing the real or current image. Then, one can best create strategies to close the gap between the real and the ideal in building a strong brand through consistent assessment, execution of relevant actions, and consistently working hard to live up to the targeted image and expectations.

Hubert Rampersad's 2009 book, Authentic personal branding, is an excellent guide for enhancing one's overall value in his/her professional life. Rampersad provides a discussion of personal branding and a framework for individuals to develop their personal brand, with a focus on practical leadership strategies. In today's competitive workplace for top jobs, personal branding will continue to be a very important consideration in the recruitment of leaders. Perhaps, in some cases, when it comes to job hunting, personal branding will be more important than company or product branding. According to Rampersad, one's personal brand emerges from one's search for his/her identity and meaning in life. A clear personal brand can provide one with positive energy and confidence in the workplace. Rampersad's book provides examples of people like Bill Gates, Oprah Winfrey, Donald Trump, Michael Jordon, Albert Einstein, Henry Ford, Walt Disney, Mother Teresa, Mahatma Gandhi, Martin Luther King, Nelson Mandela, Barack Obama and many others. It appears that people with a strong brand usually believe that they have a personal mission or duty to succeed in their calling or what they deem to be important. As such, they learn everything about their "calling" and work hard to make contributions in that area. Whether it is the building of one's personal brand or professional corporate image for a product, one must strive toward excellence, improve continuously, and make sure that he or she lives up to the expectations in both the real and ideal worlds.

\section{Summary}

The main objective of the study was to investigate brand equity in the economy beer industry of Thailand. The specific objectives of this study were to explore market strategy in the beer industry and understand beer consumption behavior among people in the Bangkok metropolis. This quantitative research collected data samples 
from groups of beer drinkers in order to discover relevant aspects of brand equity in the economy beer that affect the consumers' decision-making process. The statistical analysis demonstrated that:

- Awareness of each beer brand is statistically different than others in this study;

- Liking for each beer brand is statistically different than others in this study;

- Purchase intention of each beer brand is statistically different than others in this study;

- Satisfaction of each beer brand is statistically different than others in this study;

- Loyalty of each beer brand is statistically different than others in this study.

Furthermore, descriptive data shows that males were more likely to drink regularly, and drink beer in large quantities. The respondents were usually drinking alcoholic beverages either daily or as opportunities became available in social gatherings. All of the samples were people who drank beer before this research, and most indicated a preference for one brand of beer over others. The sample groups would be drinking beer in order to relax themselves, or to socialize at a party. They recognize Leo beer more than the Chang or Cheer beer brands. Most of the sample groups drank beer two to three times each week, and each time they would drink one bottle of beer. Implications of the findings are important for sales managers, researchers and marketers in Thailand.

This study has confirmed that brand equity measurement offers many ways to develop the concept and generate discussions. Brand equity can be either a consumer-based perspective or a firm-based perspective. As proposed herein, a multidimensional construct consisting of brand awareness and association has been found to be the most effective marketing focus for building brand image of the firm and to provide a competitive advantage to the organization. This study has confirmed the important role of brand equity factors from actual research of consumer use in the economy beer industry. The manufactures can use the information to build stronger brands in the future. Also, expatriate sales professionals and retailers coming to Thailand from the United States, Latin America, European countries or even China or other Asian countries can benchmark successful branding strategies used by the manufacturer of Leo beer which is Boonrawed Brewery Company Limited. Perhaps, through research and experimentation, the managers of Boonrawed Brewery Company Limited have learned what strategies to use in order to create a strong brand in Thailand and which techniques to avoid due to cultural, social and legal norms.

\section{References:}

Aaker, D. A.. (1991). Managing brand equity: Capitalizing on the value of a brand name. New York: The Free Press.

Boutie, P.. (2010). Who will save the brands? Communication World. Retrieved 26 January, 2010 from http://findarticles.com/p/articles/mi_m4422/is_n7_v11/ai_15687711.

Chalhoub, M.. (2009). The effect of management practices on corporate performance: An empirical study of non-governmental organizations in the Middle East. International Journal of Management, 26(1), 51-76.

Chan, L., Fine, J., Khanfar, N. \& Mujtaba, B. G.. (2009). Rebranding ethereal cereals: Responding to healthy diet campaigns through strategic planning, partnering and human relations. Journal of Case Research in Business and Economics, 1(1), 1-10.

Cobb-Walgren, Cathy, J., Ruble, C. A. \& Donthu, N.. (1995). Brand equity, brand preference and purchase intent. Journal of Advertising, 24(3), 25-40.

Johnson, W. C. \& Weinstein, A.. (2004). Superior customer value in the new economy: Concepts and cases (2nd ed.). Florida: CRC Press, St. Lucie.

Jones, G. R. \& George, J. M.. (2009). Contemporary management. New York: McGraw-Hill.

Karadjova-Stoev, G. \& Mujtaba, B. G.. (2009). Strategic human resource management and global expansion lessons from the Euro Disney challenges in France. International Business and Economics Research Journal, 8(1), 69-78.

Keller, K. L.. (1993). Conceptualizing, measuring and managing customer-based brand equity. Journal of Marketing, 57(1), p.1-22.

Keller, K. L.. (2008), Strategic brand management: Building, measuring, and managing brand equity (3rd ed.). New Jersey: Prentice 
Hall.

Kotler, P.. (1996). Marketing management. New Jersey: Prentice-Hall.

Laddawan, K.. (2005). Computer data analysis on SPSS, Consumer behavior association. Srinakharinwirot University.

Lassar, W., Mittal, B. \& Sharma, A.. (1995). Measuring customer-based brand equity. Journal of Consumer Marketing, 12(4), 11-19.

Morgan, R. P.. (2000). A customer-oriented framework of brand equity and loyalty. International Journal of Market Research, 42(3), 65-120.

Mujtaba, G. B., Luk, D. M., Murphy, E. F. Jr. \& Saowakul, W.. (Spring, 2009). The cultural value rankings of respondents in Thailand, Hong Kong and Afghanistan: Is there a convergence or divergence of values? International Journal of Business and Public Administration, 6(1), 48-68.

Mujtaba, B. G. \& McFarlane, D.. (2007). Competitive advantage and market organizations in the 21st century: Market driving or market driven. In: Farazmand, A. \& Pinkowski, J. (Eds.), Handbook of globalization, governance, and public administration. Boca Raton, United States: Taylor \& Francis, 981-1002.

Murphy Jr., E. F., Mujtaba, B. G., Manyak, T., Sungkhawan, J. \& Greenwood, R.. (2010). Generational value differences of baby boomers in Thailand. Asia Pacific Business Review (in-press). DOI: 10.1080/13602380903503762.

Ochoa, R. M. \& Mujtaba, B. G.. (2009, August). The application of historical and modern management theories in the financial industry: An analysis of how management practices affect employee turnover! Journal of Business and Economics Research, 7(8), 19-32.

Pohlman, R. \& Gardiner, G.. (2000). Value driven management: How to create and maximize value over time for organizational success. New York: AMACOM.

Rampersad, H. K.. (2009). Authentic personal branding: A new blueprint for building and aligning a powerful leadership brand. Greenwich, Connecticut: Information Age Publishing.

Sangkaworn, C. \& Mujtaba, B. G.. (2010). Marketing practices of hotels and resorts in Chiang Mai: A study of products, pricing and promotional practices. Journal of Management and Marketing Research, 4(1), 1-17.

Solomon, M. R.. (2010). Consumer behavior: Buying, having and being (9th ed.). New Jersey: Prentice Hall.

Teng, L.. (2009). A comparison of two types of price discounts in shifting consumers attitudes and purchase intention. Journal of Business Research, 62(1), 14-21.

Udechukwu, I. I. \& Mujtaba, B. G. (2007). Determining the probability that an employee will stay or leave the organization: A mathematical and theoretical model for organizations. Human Resource Development Review, 6(2), 164-184.

(Edited by Ruby and Chris) 